\title{
Temperature-dependent development and parasitism rates of four species of Pteromalidae (Hymenoptera) parasitoids of house fly (Musca domestica) pupae
}

\author{
J. A. MANN, R. C. AXTELL and R. E. STINNER* \\ Department of Entomology, North Carolina State University, Raleigh, North Carolina, U.S.A.
}

\begin{abstract}
Parasitoid development, parasitoid-induced host mortality and parasitoid progeny emergence were determined at five constant temperatures for Muscidifurax raptor Girault and Sanders, Muscidifurax zaraptor Kogan and Legner, Spalangia cameroni Perkins and Spalangia endius Walker using pupae of the house fly, Musca domestica L., as hosts. At temperatures of $20,25,30$ and $35^{\circ} \mathrm{C}$ the median development times (days from oviposition to adult emergence), respectively, were M.raptor $(28.4,20.7,14.3,14.5)$, M.zaraptor $(30.6,22.8,14.1,14.2)$, S.cameroni $(55.6,35.2,21.8,25.0)$ and S.endius $(52.4,31.5,16.3,14.6)$. All species failed to emerge at $15^{\circ} \mathrm{C}$. Using densities of five parasitoids and 100 hosts and a $24 \mathrm{~h}$ exposure period, Muscidifurax species oviposited at a greater rate over a wider range of temperatures than Spalangia species. At $15,20,25,30$ and $35^{\circ} \mathrm{C}$ the mean number of pupae killed per parasitoid were, respectively, M.raptor $(1.4,7.4,10.5$, $13.7,14.1)$, M.zaraptor $(0.0,3.3,8.9,14.4,15.0)$, S.cameroni $(0.0,7.8$, $11.0,11.9,7.4)$, S.endius $(0.6,4.0,7.5,12.0,11.7)$, and means of the number of parasitoid progeny per parasitoid were, respectively, M.raptor (0.2, 5.2, 7.9, 11.8, 11.6), M.zaraptor (1.3, 4.4, 8.2, 13.0, 13.7), S.cameroni $(0.0,2.4,4.7,5.1,1.0)$, S.endius $(0.0,0.9,3.4,7.5$, 4.9). Development and ovipositional activity in S.cameroni was strongly inhibited at $35^{\circ} \mathrm{C}$. The model by Sharpe \& DeMichele (1977) was used to describe temperature-dependent development and the number of parasitoid progeny produced per parasitoid at temperatures of $15-30^{\circ} \mathrm{C}$ in all species.
\end{abstract}

Key words. Muscidifurax raptor, Muscidifurax zaraptor, Spalangia cameroni, Spalangia endius, Musca domestica, house fly, Pteromalidae.

\section{Introduction}

Pteromalid parasitoids have been studied extensively for their potential as biological control agents of house fly (Musca domestica L.) in

Correspondence: Dr R. C. Axtell, Department of Entomology, Box 7613, North Carolina State University, Raleigh, NC 27695-7613, U.S.A. confined animal production systems (Patterson \& Rutz, 1986; Rueda \& Axtell, 1985). Activity of these parasitoids has been evaluated through numerous survey and parasitoid release studies, but a lack of sufficient detailed data on many aspects of their biology and behaviour hinder their use as biological control agents.

In insects, as in all poikilotherms, response to 
temperature is a fundamental feature determining rates of development and behavioural activity. In the Pteromalidae, the temperaturedependence of development rate has been demonstrated through laboratory experimentation in Muscidifurax raptor Girault \& Sanders and Spalangia endius Walker by Ables et al. (1976). The data suggested that seasonal differences in abundance of these species (Ables \& Shepard, 1976; Legner \& Brydon, 1966; Rutz \& Axtell, 1980) were primarily due to different responses to temperature. Effects of temperature on levels of host destruction have been reported for M.raptor, S.endius, M.uniraptor Kogan \& Legner, M.zaraptor Kogan \& Legner, S.longipetiolata Boucek, S.nigra Latreille and $S$. cameroni Perkins (Ables \& Shepard, 1976; Legner, 1977; Moon et al., 1982). Accurate models of temperature-dependent development are required for predicting parasitoid populations and seasonal abundance in fly management programmes.

The objectives of this study were to use standardized experimental conditions to compare developmental time and parasitism by M.raptor, M.zaraptor, S.cameroni and S.endius at five constant temperatures, ranging from 15 to $35^{\circ} \mathrm{C}$, using house fly pupae as hosts.

In order to use the data in simulation models being developed for integrated fly management programmes, the effects of temperature on development and parasitism were quantified using the four-parameter version of the Sharpe \& DeMichele (1977) model. This model is based on the thermodynamics of biological reactions and the inactivation of controlling enzymes at temperature extremes. It describes an approximate linear response at intermediate temperatures, a decreased response at high temperatures due to enzyme denaturation (high temperature inhibition) and a decreased response at low temperatures due to enzyme inactivation (low temperature inhibition). A computer programme written by Wagner et al. (1984) was used, along with modifications, to estimate the parameters of this model for temperaturedependent parasitoid development and number of progeny produced per parasitoid.

\section{Materials and Methods}

House flies were maintained in screen cages $\left(27^{\circ} \mathrm{C}, 70 \%\right.$ r.h., photoperiod $\left.14 \mathrm{~L}: 10 \mathrm{D}\right)$ on a diet of milk and granulated sucrose. Fly larvae were reared in a 2-litre screen-topped plastic container filled with medium consisting of a mixture of standard fly medium (CMSA medium; Ralston Purina Co., St Louis, Mo., U.S.A.), water and yeast (200:120:1). After pupation, the pupae in the upper, drier portions of the medium were removed and the remnants of the medium blown off (Bailey, 1970). In order to obtain pupae of a known age, a metal sieve ( $2.0 \mathrm{~mm}$ openings) was used to separate larvae from pupae at known intervals of time. In all experiments, pupae used were $24-28 \mathrm{~h}$ old, 5.6-5.8 mm long $\times 2.3-2.5 \mathrm{~mm}$ diameter, and weighed $16-18 \mathrm{mg}$.

The stock cultures of parasitoids were maintained in sleeved plexiglass cages $(18 \times 18 \times$ $18 \mathrm{~cm}$ ) with $20 \mathrm{~cm}^{2}$ windows covered by wire mesh $(0.2 \mathrm{~mm}$ openings) in the three walls for ventilation. Parasitoids were given fresh, $<3$-day-old, house fly pupae weekly for oviposition and feeding. Pupae from the cages were removed, held in screen-topped clear plastic cups at $27 \pm 3^{\circ} \mathrm{C}, 70 \%$ r.h., $14 \mathrm{~L}: 10 \mathrm{D}$, and returned to the cages when the parasitoids emerged. While experiments were in progress, fly pupae were replaced every 2 days in order to augment parasitoid populations.

Developmental rates at constant temperatures. Fly pupae were spread $1-2 \mathrm{~cm}$ deep in circular dishes (diameter $13 \mathrm{~cm}$ ) and exposed to the parasitoids in the rearing cages of M.raptor, M.zaraptor, S.cameroni and S.endius. After $24 \mathrm{~h}$ the fly pupae were removed and sieved (mesh openings $1.7 \mathrm{~mm}$ ) to separate the pupae from the parasitoids. For each parasitoid species, aliquots of 100 pupae were placed in each of ten covered plastic cups (height $11 \mathrm{~cm}$, volume $360 \mathrm{ml}$ ). Two cups per species, along with a control cup containing unexposed pupae, were placed in incubators at 15,20,25, 30 and $35^{\circ} \mathrm{C}( \pm 1.5)$ with a photoperiod of $14 \mathrm{~L}: 10 \mathrm{D}$. This procedure was repeated on three different days giving six replications per treatment $(n=600)$. In these experiments, parasitism (based on percentage emergence of parasitoids assuming only one parasitoid emerges per pupa) ranged from $45 \%$ to $65 \%$ and pupal mortality ranged from $80 \%$ to $100 \%$.

The cups in the incubators were observed daily, and after fly emergence was complete the flies were removed and counted. Subsequently, the emerging parasitoids, which took longer to 
peak development rate (or number of progeny per parasitoid) for estimation of the parameters. Goodness of fit for each model was tested using a linear regression of the predicted versus the observed values to calculate the $R^{2}$, and test for a slope of 1 and intercept of zero. To compare information on the development rates of S.endius and M.raptor from different cultures, parameter estimations were also made for those two species using our data together with comparable observations from Ables et al. (1976).

As insect emergence at a constant temperature is not itself constant, variation was modelled using the approach by Stinner et al. (1975). The concepts of physiological time and the distribution of development over this physiological time scale is discussed in detail in Wagner et al. (1984). It was assumed that the first individuals completed development at 0.8 of the median development, $50 \%$ of the individuals at a median development of 1.0 and $100 \%$ at a median development of 1.3 . The equation describing the cumulative proportion of the population completing development $(y)$ at median physiological time $(p)$ is:

$$
y=(1-z)^{2.1013^{z^{2}}}
$$

(where $z=(1.3-p) /(1.3-0.8))$.

The distribution of development is expressed, thus, as a function of the median development

Table 1. Mean $( \pm S D)$, median (observed and predicted) number of days for development of four species of Pteromalidae from oviposition to adult emergence at five constant temperatures.

\begin{tabular}{|c|c|c|c|c|c|c|}
\hline \multirow[b]{2}{*}{ Species } & \multirow[b]{2}{*}{${ }^{\circ} \mathrm{C}$} & \multirow{2}{*}{$\begin{array}{l}\text { Total no. } \\
\text { parasitoids } \\
\text { emerged }\end{array}$} & \multicolumn{4}{|c|}{ No. days of adult emergence } \\
\hline & & & Mean* & $\begin{array}{l}\text { Observed } \\
\text { median }\end{array}$ & $\begin{array}{l}\text { Predicted } \\
\text { median }\end{array}$ & $R^{2 \dagger}$ \\
\hline \multirow[t]{5}{*}{ M.raptor } & 15 & 0 & - & - & 42.5 & \multirow[t]{5}{*}{0.99} \\
\hline & 20 & 396 & $29.2 \pm 0.8^{\mathrm{a}}$ & 28.4 & 28.9 & \\
\hline & 25 & 333 & $21.3 \pm 0.1^{\mathrm{b}}$ & 20.7 & 20.1 & \\
\hline & 30 & 316 & $14.9 \pm 0.2^{c}$ & 14.3 & 14.7 & \\
\hline & 35 & 77 & $14.7 \pm 0.2^{c}$ & 14.5 & 14.5 & \\
\hline \multirow{5}{*}{ M.zaraptor } & 15 & 0 & - & - & 48.9 & \multirow[t]{5}{*}{0.97} \\
\hline & 20 & 301 & $31.3 \pm 0.5^{\mathrm{a}}$ & 30.6 & 31.9 & \\
\hline & 25 & 358 & $23.4 \pm 0.1^{\mathrm{b}}$ & 22.8 & 21.4 & \\
\hline & 30 & 420 & $14.8 \pm 0.2^{\mathrm{c}}$ & 14.1 & 14.8 & \\
\hline & 35 & 247 & $15.0 \pm 0.3^{\mathrm{c}}$ & 14.2 & 14.2 & \\
\hline \multirow[t]{5}{*}{ S.cameroni } & 15 & 0 & - & - & 99.3 & \multirow[t]{5}{*}{0.99} \\
\hline & 20 & 192 & $56.3 \pm 1.9^{\mathrm{a}}$ & 55.6 & 56.9 & \\
\hline & 25 & 269 & $36.3 \pm 0.5^{\mathrm{b}}$ & 35.2 & 34.0 & \\
\hline & 30 & 81 & $22.5 \pm 0.4^{\mathrm{c}}$ & 21.8 & 22.4 & \\
\hline & 35 & 4 & $29.5 \pm 4.5^{\mathrm{bc}}$ & 25.0 & 25.1 & \\
\hline \multirow[t]{5}{*}{ S.endius } & 15 & 0 & - & - & 105.6 & \multirow[t]{5}{*}{0.99} \\
\hline & 20 & 145 & $53.6 \pm 0.9^{\mathrm{a}}$ & 52.4 & 54.9 & \\
\hline & 25 & 388 & $31.9 \pm 0.8^{\mathrm{b}}$ & 31.5 & 29.9 & \\
\hline & 30 & 317 & $17.2 \pm 0.4^{c}$ & 16.3 & 16.5 & \\
\hline & 35 & 205 & $15.4 \pm 0.3^{c}$ & 14.6 & 14.6 & \\
\hline
\end{tabular}

* Means followed by the same letters in a column within a species were not significantly different $(P<0.05$, Tukey's procedure).

${ }^{\dagger} R^{2}$ of predicted versus observed median number of days of adult emergence. In all cases the slope was not significantly different from 1 and intercept was not significantly different from 0 . All $R^{2}$ 's were significant at $P<0.01$. 
develop, were removed from each cup by aspirator and counted daily. After parasitoid emergence was complete (evidenced by 1 week of no further emergence) the experiment was terminated. Mean and median development times were calculated for each species and percentage fly mortality was corrected for mortality $(2-7 \%)$ in the control (Abbott, 1925). Mean development times were analysed using a two-way analysis of variance for a completely randomized design (PROC GLM; SAS Institute, 1982). Blocking by days was not incorporated into the analysis because one temperature treatment was repeated after incubator failure.

Rates of parasitism at constant temperatures. Standard chambers and procedures were used to expose fly pupae to the four species of parasitoids at five constant temperatures. The chambers were plastic cups $(360 \mathrm{ml})$ filled to a depth of $7 \mathrm{~cm}$ with dry fly rearing medium (CMSA medium). A plastic mesh bag $(5.5 \mathrm{~cm}$ diameter, $1.5 \mathrm{~mm}$ openings) containing $100 \mathrm{fly}$ pupae was placed on top of the medium in each cup and covered with $1.5 \mathrm{~cm}$ of dry poultry manure (moisture $10 \%$ ), which had been sieved (mesh openings $1.5 \mathrm{~cm}$ ) and frozen for $48 \mathrm{~h}$ prior to use. For each experiment, two cups of exposed pupae and two cups of unexposed (control) pupae were held at each constant temperature of $15,20,25,30$ and $35^{\circ} \mathrm{C} \pm 1.5$ (photoperiod 14L:10D). The cups of pupae were acclimated for $2 \mathrm{~h}$ at each temperature prior to adding parasitoids. Female parasitoids (sex determined according to Rueda \& Axtell, 1985) were removed (by aspirator) at random from the rearing cages and acclimated for $2 \mathrm{~h}$ at each temperature. Five acclimated female parasitoids were then transferred to each cup at the same temperature and held for $24 \mathrm{~h}$. Control cups were held free of parasitoids. After $24 \mathrm{~h}$ the mesh bag was removed from each cup, the fly pupae retrieved and separated from any stray parasitoids using a metal sieve $(1.7 \mathrm{~mm}$ openings), and transferred to a covered plastic cup which was held at $27 \pm 2^{\circ} \mathrm{C}$ for development of the flies and parasitoids. After emergence was complete, the flies and parasitoids were counted. This procedure was repeated on 3-5 different days (M.raptor $n=10 ;$ M.zaraptor $n=$ 6; S.cameroni $n=8$; S.endius $n=9$ ).

Pupal mortality in the presence of parasitoids was corrected for control mortality (Abbott, 1925). Percentage progeny emergence was the number of pupae yielding parasitoid progeny as a percentage of the original number of pupae, and percentage residual pupal mortality (due to host-feeding, superparasitism, and unsuccessful oviposition) was defined as the difference between the percentage pupal mortality and the percentage progeny emergence. The number of pupae killed per parasitoid and the number of parasitoid progeny per parasitoid were also calculated. Means of each of these variables were analysed using a two-way analysis of variance incorporating blocking by cup (PROC GLM; SAS Institute, 1982).

Model development. The equation by Sharpe \& DeMichele (1977), with high temperature inhibition alone, was used to describe the effect of temperature on median development rate (1/ days to complete development from oviposition to adult emergence) and rates of parasitism of house fly pupae for each species of parasitoid.

The Sharpe \& DeMichele (1977) model with high temperature inhibition has the form:

$$
r(K)=\frac{\mathrm{RH} 025 * \frac{K}{298.15} * \exp \left[\frac{\mathrm{HA}}{1.987}\left(\frac{1}{298.15}-\frac{1}{K}\right)\right]}{1+\exp *\left[\frac{\mathrm{HH}}{1.987}\left(\frac{1}{\mathrm{TH}}-\frac{1}{K}\right)\right]}
$$

where $r(K)=$ median rate of development $\left(\right.$ days $\left.^{-1}\right)$ at temperature $K$ ( ${ }^{\circ}$ Kelvin), RH025, $\mathrm{HA}, \mathrm{TH}$ and $\mathrm{HH}$ are constants associated with a hypothetical single rate-controlling enzyme are as described by Schoolfield et al. (1981). Median (fiftieth percentile) rates were used rather than mean rates because median rates are required in the calculation of the developmental distribution (see below). Parameter estimates for this equation were obtained for each data set using a SAS program (Wagner $e t$ al., 1984). This program selects the number of parameters to be used, identifies initial estimates, and then uses these values as inputs to a nonlinear regression analysis computing the least-square estimates by the Marquardt method (SAS, 1982). The equation was then used to estimate median development times and mean number of progeny per parasitoid for temperatures ranging from 10 to $40^{\circ} \mathrm{C}$. Due to convergence problems using the SAS algorithm by Wagner et al. (1984), it was necessary for three species to add an assumed data point at the 
peak development rate (or number of progeny per parasitoid) for estimation of the parameters. Goodness of fit for each model was tested using a linear regression of the predicted versus the observed values to calculate the $R^{2}$, and test for a slope of 1 and intercept of zero. To compare information on the development rates of S.endius and M.raptor from different cultures, parameter estimations were also made for those two species using our data together with comparable observations from Ables et al. (1976).

As insect emergence at a constant temperature is not itself constant, variation was modelled using the approach by Stinner et al. (1975). The concepts of physiological time and the distribution of development over this physiological time scale is discussed in detail in Wagner et al. (1984). It was assumed that the first individuals completed development at 0.8 of the median development, $50 \%$ of the individuals at a median development of 1.0 and $100 \%$ at a median development of 1.3 . The equation describing the cumulative proportion of the population completing development $(y)$ at median physiological time $(p)$ is:

$$
y=(1-z)^{2.101 z^{2^{2}}}
$$

(where $z=(1.3-p) /(1.3-0.8)$ ).

The distribution of development is expressed, thus, as a function of the median development

Table 1. Mean ( \pm SD), median (observed and predicted) number of days for development of four species of Pteromalidae from oviposition to adult emergence at five constant temperatures.

\begin{tabular}{|c|c|c|c|c|c|c|}
\hline \multirow[b]{2}{*}{ Species } & \multirow[b]{2}{*}{${ }^{\circ} \mathrm{C}$} & \multirow{2}{*}{$\begin{array}{l}\text { Total no. } \\
\text { parasitoids } \\
\text { emerged }\end{array}$} & \multicolumn{4}{|c|}{ No. days of adult emergence } \\
\hline & & & Mean* & $\begin{array}{l}\text { Observed } \\
\text { median }\end{array}$ & $\begin{array}{l}\text { Predicted } \\
\text { median }\end{array}$ & $R^{2 \dagger}$ \\
\hline \multirow[t]{5}{*}{ M.raptor } & 15 & 0 & - & - & 42.5 & 0.99 \\
\hline & 20 & 396 & $29.2 \pm 0.8^{\mathrm{a}}$ & 28.4 & 28.9 & \\
\hline & 25 & 333 & $21.3 \pm 0.1^{\mathrm{b}}$ & 20.7 & 20.1 & \\
\hline & 30 & 316 & $14.9 \pm 0.2^{\mathrm{c}}$ & 14.3 & 14.7 & \\
\hline & 35 & 77 & $14.7 \pm 0.2^{\mathrm{c}}$ & 14.5 & 14.5 & \\
\hline \multirow[t]{5}{*}{ M.zaraptor } & 15 & 0 & - & - & 48.9 & 0.97 \\
\hline & 20 & 301 & $31.3 \pm 0.5^{\mathrm{a}}$ & 30.6 & 31.9 & \\
\hline & 25 & 358 & $23.4 \pm 0.1^{\mathrm{b}}$ & 22.8 & 21.4 & \\
\hline & 30 & 420 & $14.8 \pm 0.2^{\mathrm{c}}$ & 14.1 & 14.8 & \\
\hline & 35 & 247 & $15.0 \pm 0.3^{\mathrm{c}}$ & 14.2 & 14.2 & \\
\hline \multirow[t]{5}{*}{ S.cameroni } & 15 & 0 & - & - & 99.3 & 0.99 \\
\hline & 20 & 192 & $56.3 \pm 1.9^{\mathrm{a}}$ & 55.6 & 56.9 & \\
\hline & 25 & 269 & $36.3 \pm 0.5^{\mathrm{b}}$ & 35.2 & 34.0 & \\
\hline & 30 & 81 & $22.5 \pm 0.4^{\mathrm{c}}$ & 21.8 & 22.4 & \\
\hline & 35 & 4 & $29.5 \pm 4.5^{b c}$ & 25.0 & 25.1 & \\
\hline \multirow[t]{5}{*}{ S.endius } & 15 & 0 & - & - & 105.6 & 0.99 \\
\hline & 20 & 145 & $53.6 \pm 0.9^{\mathrm{a}}$ & 52.4 & 54.9 & \\
\hline & 25 & 388 & $31.9 \pm 0.8^{\mathrm{b}}$ & 31.5 & 29.9 & \\
\hline & 30 & 317 & $17.2 \pm 0.4^{\mathrm{c}}$ & 16.3 & 16.5 & \\
\hline & 35 & 205 & $15.4 \pm 0.3^{\mathrm{c}}$ & 14.6 & 14.6 & \\
\hline
\end{tabular}

\footnotetext{
* Means followed by the same letters in a column within a species were not significantly different $(P<0.05$, Tukey's procedure).

${ }^{4} R^{2}$ of predicted versus observed median number of days of adult emergence. In all cases the slope was not significantly different from 1 and intercept was not significantly different from 0 . All $R^{2}$ s were significant at $P<0.01$.
} 
time. The relationship of development to physiological age based on this median time is constant regardless of temperature. The scale of physiological age is arbitrarily set with $50 \%$ of the insect population emerging at a physiological age of 1.0. The predicted distribution of development at each temperature and for each species was determined by multiplying the estimated rate of development at that temperature by the time for emergence (days). This was plotted against the cumulative proportion of individuals developed.

\section{Results}

\section{Developmental rate at constant temperatures}

For all four species there was a significant decrease in the number of days required for development from oviposition to adult emergence between temperatures of 20 and $30^{\circ} \mathrm{C}$ (Table 1), but no further significant decrease at $35^{\circ} \mathrm{C}$. Mean development times over these temperatures were less for both Muscidifurax species (M.raptor 29-15 days; M.zaraptor 31-15 days) than for Spalangia species (S.cameroni $56-22$ days; S.endius $54-15$ days). At $35^{\circ} \mathrm{C}$, mean development time increased in S.cameroni and exhibited a high variability ( $29.5 \pm 4.5$ days), suggesting that the upper temperature limit for development of S.cameroni was in this region. There was no parasitoid emergence at $15^{\circ} \mathrm{C}$.

The temperature-related median development rate of all species was best described by the four-parameter equation incorporating high temperature inhibition (Table 2). In all cases

Table 2. Estimated parameter values (equation of Sharp \& DeMichele, 1977) for models of temperaturedependent median rate of development (per day) of four species of Pteromalidae.

\begin{tabular}{llllr}
\hline Species & RH025 & HA & TA & \multicolumn{1}{l}{ HH } \\
\hline M.raptor & 0.04993 & 12083.1 & 309.9 & 84897.9 \\
M.zaraptor & 0.04682 & 13343.1 & 309.6 & 107362.4 \\
S.cameroni & 0.02967 & 17582.6 & 308.1 & 86095.2 \\
S.endius & 0.03370 & 20755.9 & 309.1 & 106150.0 \\
M.raptor* & 0.05605 & 17950.2 & 307.1 & 40511.1 \\
S.endius* & 0.04423 & 25452.0 & 305.5 & 40324.0 \\
\hline
\end{tabular}

\footnotetext{
* With data included from Ables et al. (1976).
}

linear regressions of predicted versus observed development rate gave an $R^{2}$ greater than 0.98 and a slope and intercept not significantly different from 1 and 0 , respectively. This indicated that the models fit the data well. In addition, when data on median development rate from Ables et al. (1976) were also included (Table 2), four-parameter models were developed and linear regressions of predicted versus observed time gave $R^{2}$ of 0.98 with M.raptor and 0.96 with $S$.endius with the slopes and intercepts not significantly different from 1 and 0 , respectively. The predicted (according to the method by Stinner et al., 1975) and observed cumulative proportion of individuals completing development as a function of estimated physiological age is presented in Fig. 1 for all four species. Divergence from the predicted curve reflect inaccuracies in the estimations of developmental rate. Hence in M.raptor and S.cameroni the estimated rates of development were slightly high at $20^{\circ} \mathrm{C}$ and slightly low at $25^{\circ} \mathrm{C}$.

M.raptor, M.zaraptor and S.endius reached maximum developmental rates of $c .0 .075$ while in S.cameroni the maximum developmental rate was c. 0.05 (Fig. 1). Optimum temperature for maximum developmental rate was $c .32^{\circ} \mathrm{C}$ in M.raptor, M.zaraptor and S.cameroni and c. $35^{\circ} \mathrm{C}$ in S.endius. S.cameroni exhibited the most distinct high temperature inhibition (Fig. 1); however, parameters developed to describe this are heavily dependent on a data point with a large error $\left(35^{\circ} \mathrm{C}, 29.5 \pm 4.5\right)$ and therefore lack precision.

\section{Rates of parasitism at constant temperatures}

For all species, percentage parasitoid induced pupal mortality and number of pupae killed per parasitoid significantly increased at temperatures of $15-30^{\circ} \mathrm{C}$, but there was no significant difference between $30^{\circ} \mathrm{C}$ and $35^{\circ} \mathrm{C}$ (Table 3 ). The percentage of host pupae yielding parasitoid progeny and the number of parasitoid progeny per parasitoid also showed significant increases between temperatures of $15-30^{\circ} \mathrm{C}$ with no significant difference between $30^{\circ} \mathrm{C}$ and $35^{\circ} \mathrm{C}$ in all species, except for a significant decrease in S.cameroni. This again suggests particular susceptibility of this species to high temperature. The maximum percentage fly kill was approximately $10 \%$ higher in Muscidifurax species (M.raptor $68.2 \%$; M.zaraptor $71.8 \%$ ) than 

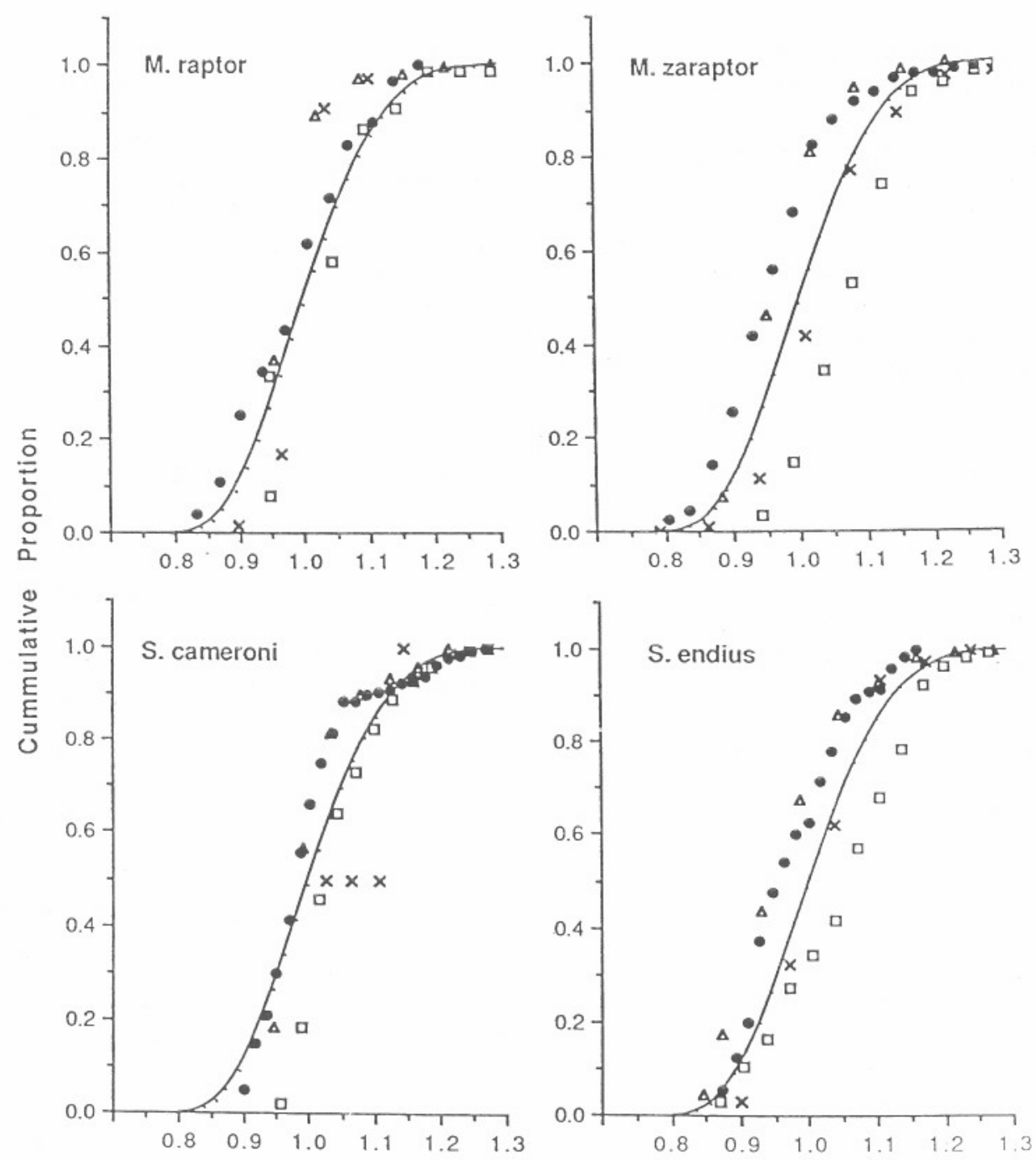

Physiological Age

Fig. 1. The cumulative proportion of the parasitoid population completing development at median physiological age (see text), in four species of Pteromalidae. The line represents the predicted distribution, calculated by the method of Stinner et al. (1975). The points represents the observed data at four temperatures $\left(-20^{\circ} \mathrm{C} ; \square, 25^{\circ} \mathrm{C}\right.$; $\left.\triangle, 30^{\circ} \mathrm{C} ; \times, 35^{\circ} \mathrm{C}\right)$.

Spalangia species (S.endius $59.5 \%$; S.cameroni $59.8 \%$ ). This generic difference was even more marked in the percentage parasitoid progeny; with Muscidifurax species having a maximum emergence of $60-70 \%$ (M.raptor $59.2 \%$; M.zaraptor $68.5 \%$ ) while S.endius and $S$. cameroni only reached a maximum of $37.3 \%$ and $25.5 \%$, respectively. Both maximum number of pupae killed per parasitoid and parasitoid progeny per parasitoid were higher in Muscidifurax species (respectively, M.raptor 14.1, 11.6; M.zaraptor 15.0, 13.7) than Spalangia species (respectively, S.cameroni 11.9, 5.1; S.endius $12.0,7.5$ ) with a significant decrease in parasitoid progeny at $35^{\circ} \mathrm{C}$ in S.cameroni.

Percentage residual mortality (pupal mortality 
Table 3. Mean $( \pm$ SD) pupal mortality and parasitoid progeny emergence from 100 house fly pupae exposed for $24 \mathrm{~h}$ to five female parasitoids of each of four species of Pteromalidae.

\begin{tabular}{|c|c|c|c|c|c|c|}
\hline \multirow[b]{2}{*}{ Species } & \multirow[b]{2}{*}{${ }^{\circ} \mathrm{C}$} & \multicolumn{3}{|c|}{ Mean $\%$ of host pupae exposed* } & \multicolumn{2}{|c|}{ No. per parasitoid* } \\
\hline & & $\begin{array}{l}\text { Pupal mortality } \\
\text { (A) }\end{array}$ & $\begin{array}{l}\text { Parasitoid progeny } \\
\text { (B) }\end{array}$ & $\begin{array}{l}\text { Residual mortality } \\
(\mathrm{A}-\mathrm{B})\end{array}$ & $\begin{array}{l}\text { Pupae } \\
\text { killed }\end{array}$ & $\begin{array}{l}\text { Parasitoid } \\
\text { progeny }\end{array}$ \\
\hline \multirow[t]{5}{*}{ M.raptor } & 15 & $6.8 \pm 10.2^{\mathrm{c}}$ & $0.9 \pm 0.7^{\mathrm{d}}$ & $5.9 \pm 10.7^{\mathrm{a}}$ & $1.4 \pm 2.0^{\mathrm{c}}$ & $0.2 \pm 0.1^{\mathrm{d}}$ \\
\hline & 20 & $37.0 \pm 6.7^{b}$ & $26.0 \pm 4.6^{c}$ & $11.0 \pm 3.9^{\mathrm{a}}$ & $7.4 \pm 1.3^{\mathrm{b}}$ & $5.2 \pm 0.9^{c}$ \\
\hline & 25 & $52.6 \pm 7.0^{\mathrm{ab}}$ & $39.5 \pm 5.0^{\mathrm{bc}}$ & $13.1 \pm 3.7^{\mathrm{a}}$ & $10.5 \pm 1.4^{\mathrm{ab}}$ & $7.9 \pm 1.0^{\mathrm{bc}}$ \\
\hline & 30 & $68.2 \pm 7.6^{\mathrm{a}}$ & $59.2 \pm 7.0^{\mathrm{a}}$ & $9.0 \pm 1.9^{\mathrm{a}}$ & $13.7 \pm 1.5^{\mathrm{a}}$ & $11.8 \pm 1.4^{\mathrm{a}}$ \\
\hline & 35 & $70.3 \pm 4.6^{\mathrm{a}}$ & $57.9 \pm 4.3^{\mathrm{ab}}$ & $12.4 \pm 0.8^{\mathrm{a}}$ & $14.1 \pm 0.9^{\mathrm{a}}$ & $11.6 \pm 0.9^{\mathrm{ab}}$ \\
\hline \multirow[t]{5}{*}{ M.zaraptor } & 15 & $0.0 \pm 4.9^{\mathrm{d}}$ & $6.5 \pm 2.1^{\mathrm{c}}$ & $0.0 \pm 3.2^{\mathrm{c}}$ & $0.0 \pm 1.0^{\mathrm{d}}$ & $1.3 \pm 0.4^{\mathrm{c}}$ \\
\hline & 20 & $16.3 \pm 7.3^{\mathrm{c}}$ & $22.2 \pm 4.9^{\mathrm{bc}}$ & $0.0 \pm 0.5^{b}$ & $3.3 \pm 1.5^{\mathrm{c}}$ & $4.4 \pm 1.0^{\mathrm{bc}}$ \\
\hline & 25 & $44.5 \pm 6.5^{\mathrm{b}}$ & $40.8 \pm 5.1^{b}$ & $3.7 \pm 3.6^{\mathrm{ab}}$ & $8.9 \pm 1.3^{\mathrm{b}}$ & $8.2 \pm 1.0^{\mathrm{b}}$ \\
\hline & 30 & $71.8 \pm 10.3^{a}$ & $65.0 \pm 8.9^{\mathrm{a}}$ & $6.8 \pm 3.4^{\mathrm{a}}$ & $14.4 \pm 2.1^{\mathrm{ab}}$ & $13.0 \pm 1.8^{\mathrm{a}}$ \\
\hline & 35 & $75.0 \pm 12.0^{\mathrm{a}}$ & $68.5 \pm 11.2^{\mathrm{a}}$ & $6.5 \pm 1.0^{\mathrm{a}}$ & $15.0 \pm 2.4^{\mathrm{a}}$ & $13.7 \pm 2.2^{\mathrm{a}}$ \\
\hline \multirow[t]{5}{*}{ S.cameroni } & 15 & $0.0 \pm 13.4^{\mathrm{b}}$ & $0.0 \pm 0.0^{c}$ & $0.0 \pm 13.4^{\mathrm{b}}$ & $0.0 \pm 2.7^{\mathrm{b}}$ & $0.0 \pm 0.0^{\mathrm{c}}$ \\
\hline & 20 & $39.0 \pm 3.9^{\mathrm{a}}$ & $11.8 \pm 1.6^{\mathrm{b}}$ & $27.3 \pm 3.6^{\mathrm{a}}$ & $7.8 \pm 0.8^{\mathrm{a}}$ & $2.4 \pm 0.3^{\mathrm{b}}$ \\
\hline & 25 & $55.2 \pm 2.8^{\mathrm{a}}$ & $23.5 \pm 2.6^{\mathrm{a}}$ & $31.7 \pm 2.3^{\mathrm{a}}$ & $11.0 \pm 0.6^{\mathrm{a}}$ & $4.7 \pm 0.5^{\mathrm{a}}$ \\
\hline & 30 & $59.5 \pm 3.3^{\mathrm{a}}$ & $25.5 \pm 2.8^{\mathrm{a}}$ & $40.0 \pm 2.8^{\mathrm{a}}$ & $11.9 \pm 0.7^{\mathrm{a}}$ & $5.1 \pm 0.6^{\mathrm{a}}$ \\
\hline & 35 & $37.2 \pm 5.9^{\mathrm{a}}$ & $4.8 \pm 1.2^{\mathrm{bc}}$ & $32.5 \pm 5.1^{\mathrm{a}}$ & $7.4 \pm 1.2^{\mathrm{a}}$ & $1.0 \pm 0.2^{\mathrm{bc}}$ \\
\hline \multirow[t]{5}{*}{ S.endius } & 15 & $2.7 \pm 5.1^{\mathrm{c}}$ & $0.0 \pm 0.0^{\mathrm{d}}$ & $2.8 \pm 5.1^{\mathrm{c}}$ & $0.6 \pm 1.0^{\mathrm{c}}$ & $0.0 \pm 0.0^{\mathrm{d}}$ \\
\hline & 20 & $20.1 \pm 6.5^{b c}$ & $4.4 \pm 1.1^{\mathrm{cd}}$ & $15.6 \pm 5.8^{\mathrm{bc}}$ & $4.0 \pm 1.3^{b c}$ & $0.9 \pm 0.2^{\text {cd }}$ \\
\hline & 25 & $37.7 \pm 5.4^{\mathrm{b}}$ & $17.2 \pm 2.6^{b c}$ & $20.5 \pm 3.7^{\mathrm{ab}}$ & $7.5 \pm 1.1^{\mathrm{ab}}$ & $3.4 \pm 0.5^{b c}$ \\
\hline & 30 & $59.8 \pm 6.9^{\mathrm{a}}$ & $37.3 \pm 6.3^{\mathrm{a}}$ & $22.5 \pm 4.4^{\mathrm{ab}}$ & $12.0 \pm 1.4^{\mathrm{a}}$ & $7.5 \pm 1.3^{\mathrm{a}}$ \\
\hline & 35 & $58.5 \pm 5.3^{\mathrm{a}}$ & $24.7 \pm 4.0^{\mathrm{ab}}$ & $33.8 \pm 3.4^{\mathrm{a}}$ & $11.7 \pm 1.0^{\mathrm{a}}$ & $4.9 \pm 0.8^{\mathrm{ab}}$ \\
\hline
\end{tabular}

* Means followed by the same letters in a column within a species were not significantly different $(P<0.05$, Tukey's procedure).

due to parasitoid host-feeding, superparasitism or unsuccessful oviposition) increased significantly between temperatures of $15-25^{\circ} \mathrm{C}$ in M.zaraptor and S.endius and $15-20^{\circ} \mathrm{C}$ in S.cameroni; however, for M.raptor there were no significant differences among temperatures. There was a significant difference in parasitoidinduced pupal kill and parasitoid progeny emergence among cups in M.raptor and M.zaraptor, supporting use of the randomized complete block design to eliminate error due to individual parasitoid variation.

In all four species the four-parameter model was used to quantify the relationship between temperature and parasitoid progeny per parasitoid (Table 4). In all cases linear regressions of predicted versus observed number of parasitoid progeny indicated that the models fit the data well $\left(R^{2}>0.95\right.$, slope and intercept not significantly different to 1 and 0 , respectively). The models indicated a stronger high temperature inhibition in Spalangia species than in Muscidifurax species, but there was insufficient data to describe low temperature inhibition.

Table 4. Estimated parameter values (equation of Sharp \& DeMichele, 1977) for models of the temperature-dependent rates of parasitism (number of progeny emerging per parasitoid) by four species of Pteromalidae.

\begin{tabular}{lrllr}
\hline Species & RH025 & HA & TA & \multicolumn{1}{l}{ HH } \\
\hline M.raptor & 8.321 & 15991.9 & 308.9 & 60231.2 \\
M.zaraptor & 10.879 & 31373.0 & 303.0 & 45480.8 \\
S.cameroni & 4.896 & 24117.6 & 303.3 & 110712.6 \\
S.endius & 3.651 & 47853.1 & 303.4 & 88859.6 \\
\hline
\end{tabular}




\section{Discussion}

At the low temperatures of 20 and $25^{\circ} \mathrm{C}$, Muscidifurax species had faster median development times (M.raptor 28.4, 20.7 days; M.zaraptor 30.6, 22.8) than Spalangia species (S.endius 52.4, 31.5; S.cameroni 55.6, 35.5) while at $35^{\circ} \mathrm{C}$ median development time was similar for all species (M.raptor 14.5, M.zaraptor 14.2, S.endius 14.6) except S.cameroni (25.0). This drop in developmental rate at $35^{\circ} \mathrm{C}$ suggested the upper lethal temperature limit was close to this point for S.cameroni. Developmental data were comparable with those of Ables et al. (1976) for S.endius and M.raptor, by Morgan \& Patterson (1975) for S.endius (18-20 days at $27-28^{\circ} \mathrm{C}$ ) and by Legner \& Gerling (1967) for M.raptor (17-22 days at $\left.26^{\circ} \mathrm{C}\right)$ and S.cameroni (24-27 days at $\left.26^{\circ} \mathrm{C}\right)$. All species failed to emerge at $15^{\circ} \mathrm{C}$, supporting the suggestion by Ables et al. (1976) that development is not completed when parasitized pupae are exposed to low temperatures over a prolonged period of time.

According to field observations, Muscidifurax species are more abundant during the cool months, while Spalangia species are more abundant during warm months (Ables \& Shepard, 1976; Legner \& Brydon, 1966; Rutz \& Axtell, 1980). The faster development of Muscidifurax species than Spalangia species at low temperatures would explain this differential seasonal abundance. High temperature inhibition seen in S.cameroni may also explain the prevalence of this species in late summer through autumn in North Carolina, U.S.A. (Rutz \& Axtell, 1980) when temperatures are lower than in midsummer.

The models developed for parasitoid emergence accurately described the data. A more detailed examination of the response at low and high temperature extremes might improve precision for these temperatures, particularly in M.zaraptor and S.cameroni. However, in confined animal production systems, where these models will be most useful in predicting population levels and determining release strategies, extreme temperatures are rare.

Results from the second set of experiments showed that host attack rate differed with temperature. Muscidifurax oviposited at a greater rate and over a wider range of temperatures than Spalangia species. Muscidifurax species were able to oviposit successfully at all temperatures, with no significant decrease at $35^{\circ} \mathrm{C}$, but only a low rate at $15^{\circ} \mathrm{C}$. In contrast, Spalangia species were not active at $15^{\circ} \mathrm{C}$, and at $35^{\circ} \mathrm{C}$ host attack rate decreased. This supports Moon et al. (1982), who demonstrated with S.cameroni that progeny per female peaked at $31.7^{\circ} \mathrm{C}$ and decreased to reach an upper limiting temperature of $36.4^{\circ} \mathrm{C}$. This high temperature inhibition was not demonstrated by Ables \& Shepard (1976) or Legner (1967) who found that oviposition is a function of both time and temperature, with Spalangia species compensating during a $36 \mathrm{~h}$ period for the initial drop seen over $24 \mathrm{~h}$, to cause higher levels of host mortality than Muscidifurax species. This may be explained in part by acclimation, which was not allowed for in their experiments. Models characterizing the relationship between temperature and successful oviposition would more accurately describe the interaction, if the influence of exposure time were incorporated.

In these experiments, cultures of M.raptor and S.cameroni were recently established in comparison to cultures of S.endius and M.zaraptor which were imported from California (1983) and Florida (1978), respectively. Prolonged laboratory culturing may considerably alter both behavioural and physiological characteristics (Legner, 1979; Legner \& Warkintin, 1985). The variation between data on development rates reported here and those by Ables et al. (1976) is understandable. However, since it was possible to estimate a single set of model parameters for both sets of data, development times appear to be comparable despite the prolonged culturing and different rearing conditions.

\section{Acknowledgments}

The authors thank T. D. Edwards for assisting in rearing the insects and construction of chambers. This is Paper No. 12192 of the Journal Series of the North Carolina Agricultural Research Service, Raleigh, N.C., U.S.A. This research was supported in part by USDACooperative States Research Service Grants No. 86-CSRS-2-2889 and 89-34103-4240.

\section{References}

Abbott, W.S. (1925) A method of computing the effectiveness of an insecticide. Journal of Economic 
Entomology, 18, 265-267.

Ables, J.R. \& Shepard, M. (1976) Influence of temperature on oviposition by the parasites Spalangia endius and Muscidifurax raptor. Environmental Entomology, 5, 511-513.

Ables, J.R., Shepard, M. \& Holman, J.R. (1976) Development of the parasitoids Spalangia endius and Muscidifurax raptor in relation to constant and variable temperature: simulation and validation. Environmental Entomology, 5, 329-332.

Bailey, D.L. (1970) Forced air for separating pupae of house flies from rearing medium. Journal of Economic Entomology, 63, 331-333.

Legner, E.F. (1967) Behaviour changes in the reproduction of Spalangia cameroni, S.endius, M.raptor and N.vitripennis (Hymenoptera: Pteromalidae) at increasing fly host densities. Annals of the Entomological Society of America, 60, 819-826.

Legner, E.F. (1977) Temperature, humidity and depth of habitat influencing host destruction and fecundity of muscoid fly parasites. Entomophaga, 22, 199-206.

Legner, E.F. (1979) Prolonged culture and inbreeding effects on reproductive rates of two pteromalid parasites of muscoid flies. Annals of the Entomological Society of America, 72, 114-118.

Legner, E.F. \& Brydon, H.W. (1966) Suppression of dung-inhabiting fly populations by pupal parasites. Annals of the Entomological Society of America, 59, 638-651.

Legner, E.F. \& Gerling D. (1967) Host-feeding and oviposition on Musca domestica by Spalangia cameroni, Nansonia vitripennis and Muscidifurax raptor (Hymenoptera: Pteromalidae) influences longevity and fecundity. Annals of the Entomological Society of America, 60, 678-691.

Legner, E.F. \& Warkentin, R.W. (1985) Genetic improvement and inbreeding effects in culture of beneficial arthropods. Proceedings of the California Mosquito and Vector Control Association, 53, 156-161.

Moon, R.D., Berry, I.L. \& Petersen, J.J. (1982) Reproduction of Spalangia cameroni Perkins
(Hymenoptera: Pteromalidae) on stable fly (Diptera: Muscidae) in the laboratory. Journal of the Kansas Entomological Society, 55, 77-85.

Morgan, P.B. \& Patterson, R.S. (1975) Field parasitisation of houseflies by natural populations of Pachychrepoideus vindemiae (Rondani), Muscidifurax raptor Girault and Sanders and Spalangia nigroaenea Curtis. Florida Entomologist, 58, 202.

Patterson, R.S. \& Rutz, D.A. (eds) (1986) Biological control of muscoid flies. Entomological Society of America, Miscellaneous Publications, 61, 1-174.

Rueda, L.M. \& Axtell, R.C. (1985) Guide to common species of pupal parasites (Hymenoptera: Pteromalidae) of the house fly and other muscoid flies associated with poultry and livestock. North Carolina Agricultural Research Service Technical Bulletin, 278, 1-88.

Rutz, D.A. \& Axtell, R.C. (1980) House fly parasites (Hymenoptera: Pteromalidae) associated with poultry manure in North Carolina. Environmental Entomology, 9, 175-180.

SAS Institute (1982) SAS User's Guide: Statistics. SAS Institute, Cary, N.C., U.S.A.

Schoolfield, R.M., Sharpe, P.J.H. \& Magnuson, C.E. (1981) Nonlinear regression of biological temperature-dependent rate models based on absolute reaction-rate theory. Journal of Theoretical Biology, 88, 719-731.

Sharpe, J.H. \& DeMichele, D.W. (1977) Reaction kinetics of poikilotherm development. Journal of Theoretical Biology, 64, 649-670.

Stinner, R.E., Butler, G.D., Jr, Bacheler, J.S. \& Tuttle, C. (1975) Simulation of temperaturedependant development in population dynamic models. Canadian Entomologist, 107, 1167-1174.

Wagner, T.L., Hsin-I Wu, Sharpe, P.J.H. \& Coulson, R.N. (1984) Modelling distributions of insect development time: a literature review and application of the Weibull function. Annals of the Entomological Society of America, 77, 475-483.

Accepted 28 September 1989 